has been received with much regret by his many friends and former pupils. Franklin went to Oxford after service in the First World War. He obtained a first-class degree in the Final Honours School of Physiology, studied medicine at St. Bartholomew's Hospital and returned to Oxford as a Fellow of Oriel College in 1924. He was a demonstrator in pharmacology from then until 1935 when he was appointed assistant director of the Nuffield Institute for Medical Research. He was dean of the Oxford Medical School for many years, and went to St. Bartholomew's as professor of physiology in 1947. Prof. Franklin was very interested in the venous side of the cardiovascular system, an interest which led in 1933 to collaboration with Prof. Janker, of Bonn, one of the pioneers of X-ray cinematography. When the Nuffield Institute for Medical Research was established in 1935, special provision was made for the study of X-ray cinematography as applied to medical problems. Within a few years Franklin's foresight was justified by the first experimental demonstration of the course of the fotal circulation. This work, in collaboration with Dr. A. E. Barclay and Sir Joseph Barcroft, finally settled a controversy which had lasted for nearly two centuries, and also provided the first direct evidence as to the nature of the changes in the circulation after birth. In 1947 the same method applied to the kidney led to the publication of some exciting and controversial "Studies of the Renal Circulation" in collaboration with Trueta, Barclay, Daniel and Prichard. Apart from Prof. Franklin's interest in the venous system (a "Monograph on Veins" was published in 1937, and "Cardiovascular Studies" in 1948), his meticulous researches into the history of physiology and his facsimile editions and translations of early writers on the circulation have earned the gratitude and respect of his colleagues. Within the past two years he has followed these with admirable translations of Harvey's "De Motu Cordis" and "De Circulatione Sanguinis".

Prof. M. de Burgh Daly

Prof. Michael de Burgh Daly, who has been appointed to succeed Prof. K. J. Franklin in the University chair of physiology at St. Bartholomew's Hospital Medical College, is also particularly interested in the control of the circulation and respiration. After taking the B.A. degree in Cambridge in 1944, he proceeded to St. Bartholomew's Hospital and qualified M.B., B.Chir. in 1947. After a house appointment, he joined Prof. G. L. (now Sir Lindor) Brown in the Department of Physiology at University College, London, and began research with the late Alfred Schweitzer. His interests in circulatory and respiratory physiology stem to some extent from the influence of Schweitzer and from that of his distinguished father, Dr. Ivan de Burgh Daly, until recently director of the Institute for Animal Research at Babraham, who has made great contributions to these subjects. Prof. de Burgh Daly spent 1952--53 in Philadelphia as Rockefeller Fellow in Prof. Schmidt's department. On his return he was appointed Locke Research Fellow of the Royal Society. His research activity has been considerable and fruitful. Among a long list of papers, notable have been those on the baroreceptor regulation of cardiac output, on the blood supply and oxygen usage of the carotid body and on chemoreflex responses of the pulmonary circulation.
Botany at Edinburgh : Prof. R. Brown, F.R.S.

THE appointment of Dr. Robert Brown to the regius chair of botany in the University of Edinburgh. in succession to the late Sir William Wright-Smith, can scarcely fail to mark a new chapter in the history of botany in Scotland. The Department of Botany in Edinburgh has a long and honourable tradition of taxonomy, and Dr. Brown has achieved a notable reputation as a plant physiologist with a very individual outlook; his activities in this new sphere will be watched with the liveliest interest. His earlier work includes contributions to the study of the stimulation of germination in seeds of the parasite Striga by root exudates from the host; but the bias of his more recent researches has arisen from the development and imaginative exploitation of a powerful new technique for the estimation of cell numbers in growing-points and the tissues immediately behind them. The combination of a maceration technique with a hæmacytometer cell-counting method has made it possible to express the results of chemical and other estimations on a per cell basis. This has given the impetus to a remarkable series of studies of the development of cells from growing. points, carried out by Dr. Brown and his co-workers, first at Leeds and later (from 1953) in his very active Agricultural Research Council Unit of Plant Cell Physiology at Oxford. A brief summary of Dr. Brown's career appeared in Nature of October 11 (p. 992).

\section{Pharmaceutical Society of Great Britain}

A PoRtrais of the late Prof. John Attfield, for thirty-four years professor of practical chemistry to the Pharmaceutical Society of Great Britain, was presented to the Society after the October meeting of the Council by his grandson, $\mathrm{Mr}$. C. A. Brooks, of Dedham, Essex. The portrait is a replica of one given to Chicago pharmacists which was painted in recognition of the work done by Prof. Attfield in helping to "raise their College from its ashes after the Great Fire of 1871 ". With the portrait, Mr. Brooks handed to the Society a complete set of the nineteen editions of his grandfather's famous textbook of pharmaceutical chemistry and an album containing an illuminated address and 1,240 signatures of professional colleagues, including those of Lord Lister, Sir William Crookes and Sir Henry Wellcome. In accepting the gifts, Mr. Hudson, president of the Pharmaceutical Society, said they would be a perpetual reminder of the prominent place Prof. Attfield occupied in the Society's history and in the scientific world; and of the services ho had rendered to pharmacy and to medicine. He served the Society from 1862 until 1896. Probably, said Mr. Hudson, Attfield's greatest achievement was his work for the "British Pharmacopœia" ; and by the time of his death he had the satisfaction of knowing that it was legally adopted in all British Dominions.

\section{Josiah Wedgwood and Research}

IN his 1957 presidential address to the North Staffordshire Field Club, J. Leighton directed attention to letters written by the famous eighteenth century potter, Josiah Wedgwood, to his colleague, and later, partner, 'Thomas Bentley (Trans. N. Staff. Field Club, 91 ; 1958). The letters show how, in company with other Staffordshire potters, Wedgwood planned so early as $1755-56$ a co-operative research establishment for the pottery industry. 